\title{
Non-cytotoxic antibodies in chronic lymphocytic leukaemia
}

\author{
A M MACLEOD, E J MINFORD, D J KING, A A DAWSON, N B BENNETT, \\ G R D CATTO
}

From the Department of Medicine, University of Aberdeen, Scotland

SUMMARY Non-cytotoxic Fc receptor blocking antibodies against autologous B lymphocytes were sought in sera from patients with chronic lymphocytic leukaemia (CLL), using a rosette inhibition assay. They were found in 11 of $52(21 \%)$ of patients with CLL, but were not associated with previous blood transfusion or pregnancy, suggesting that they were unlikely to have resulted from allogeneic stimulation. Fc receptor blockade was more commonly detected in sera from patients with stage B rather than stage A CLL (Binet classification), though this did not achieve significance beyond the $90 \%$ level, and it was noted in $62.5 \%$ of those with lymphocyte doubling times of less than one year, compared with $36.3 \%$ of those whose lymphocyte doubling time was more than one year. The results indicate that autologous Fc receptor blocking antibody activity occurs in sera from patients with CLL, is more likely to be generated by the tumour itself than by allogeneic stimulation, and is associated with increased tumour load. Such antibodies may permit tolerance of tumour by the host.

Blocking factors in tumour immunology were first described in mice with virus induced sarcomata. ${ }^{12}$ These blocking factors were believed to shield antigenic sites on the tumour cells from the sensitised lymphoid cells of the host, thus allowing the tumour cells to proliferate.

Potentially protective antibodies have been reported in non-malignant disease. It has been shown that there is a notable improvement in renal transplant survival in man when certain non-cytotoxic Fc receptor blocking antibodies are present in serum obtained from recipients before transplantation. ${ }^{3}$ Such antibodies develop in the sera of patients with chronic renal failure, who receive dialysis, during courses of blood transfusions given preoperatively to improve allograft survival. ${ }^{4}$ Transfusion taking place before renal transplantation may therefore induce antidonor, non-cytotoxic Fc receptor blocking antibodies, which are associated with improved allograft survival.

Similar antibodies directed towards paternal lymphocytes have been found in sera from pregnant and parous women ${ }^{5}$; such blocking antibodies were not found in serum from women undergoing spontaneous

Accepted for publication 5 February 1987 abortion. Fc receptor blocking antibodies, which are associated with successful transplantation and normal pregnancy, may thus help to protect foreign tissue from rejection by the host. These Fc receptor blocking antibodies are directed against $B$ lymphocyte antigens dissimilar to the classically defined major histocompatibility complex antigens, although family studies showed that they were HLA linked. ${ }^{5}$

Chronic lymphocytic leukaemia (CLL) is a malignant disease, usually of $B$ cell origin, characterised by progressive accumulation of monoclonal B cells, many in the peripheral blood, and thus accessible for investigation. The erythrocyte antibody (EA) 옥 inhibition assay could be used conveniently, testing $D$ the sera of patients with CLL against their autologous B cells as target cells, to study the development of $N$ possible protective antibodies against tumour cells.

Measurement of the prognostically important features in CLL is well established, using assessments of both tumour bulk and the rate of progression of the disease. Two staging systems ${ }^{67}$ have been used to 0 estimate tumour bulk, and the doubling time of $\Phi$ peripheral blood lymphocytes is thought to be a good? measure of tumour growth. ${ }^{8}$ If blocking antibodies were present in the sera of patients with CLL they might be important in the prognosis of the disease.

The aims of the study were firstly, to determine $\stackrel{\mathbb{Q}}{2}$ whether non-cytotoxic antibodies are present in sera 
from patients with CLL directed against their own lymphocytes; secondly, to correlate antibody development with clinical prognostic features; and, finally, to find out whether the antibody response was selective when tested against a lymphocyte panel, and whether activity reflected the HLA types of the target cells.

\section{Patients and methods}

Fifty two patients ( 40 men and 12 women, mean age 63.3 years) with B-CLL were studied. Table 1 shows the tumour staging by both the Rai and the Binet classifications. In addition, lymphocyte doubling times, previous pregnancies and blood transfusions, treatment with cytotoxic drugs, previous or concomitant malignant diseases, and the results of the direct antiglobulin test, were recorded.

Serum samples $(4 \mathrm{ml})$ were obtained, heat inactivated at $56^{\circ} \mathrm{C}$ for 45 minutes, and ultracentrifuged at $100000 \mathrm{~g}$ for 90 minutes to remove immune complexes.

Autologous B lymphocytes were obtained from heparinised whole blood using Ficoll sodium diatrizoate density gradient centrifugation. Cells collected at the interface were washed three times in phosphate buffered saline (PBS), and resuspended in RPMI with $10 \%$ fetal calf serum at a concentration of $5 \times 10^{6} / \mathrm{ml}$. Normal panel lymphocytes were separated into $T$ and $B$ cell subpopulations using the nylon wool column method. ${ }^{9}$

EA rosette inhibition was carried out by a modification $^{3}$ of a previously described method. ${ }^{10}$ Target lymphocytes which had previously been incubated with test serum, or fetal calf serum as control, were further incubated with erythrocyte antibody complexes (EAs). Binding of antibody in test serum to B lymphocytes was shown by inhibition of rosette formation between the EAs and Fc receptors on the target autologous B lymphocytes. ${ }^{4}$ EA inhibiting activity was calculated as follows:

$$
\% \mathrm{EAI}=\left[1-\frac{(1-\% \text { EA rosettes in test serum })}{(\% \text { EA rosettes in FCS control })}\right] \times \frac{100}{1}
$$

Inhibition was accepted as positive when $20 \%$ or higher. ${ }^{11}$

Confidence intervals were applied to the proportion of those patients with EA inhibiting antibody at each stage in the Rai and Binet classification according to the standard formula ${ }^{12}$ :

$$
\sqrt{\frac{P-P}{\mathrm{P}-(1-P)}} \sim N(0 \cdot 1)
$$

Confidence intervals were calculated at $90 \%$ and $95 \%$ levels for each group and represented graphically as ranges. Groups were judged to be significantly different if the ranges for each did not overlap.

\section{Results}

EA inhibiting antibodies against autologous B lymphocytes were detected in 11 of $52(21 \%)$ of patients (table 2).

\section{ANTIBODY DEVELOPMENT}

Seven of the 12 women $(53.8 \%)$ tested were parous, and none of these seven showed positive results in the assay. The development of antibody was thus not associated with previous pregnancy.

Previous blood transfusions Two of $19(10 \cdot 5 \%)$ previously transfused patients had serological evidence of EA inhibition, compared with nine of $33(27 \%)$ of those who had never been transfused. There was no association between antibody development and previous blood transfusion.

Tumour staging The number of patients in each stage with serological evidence of EA inhibiting activity was recorded (table 2). Inhibitory activity against autologous lymphocytes was more commonly detected in patients with stage B-CLL than in those with stage A disease (Binet classification). This difference did not achieve significance beyond the $90 \%$ level. None of the sera from the six patients with stage C-CLL showed such antibody activity. A graded increase in autoantibody activity was noted between stage 0 and II in the Rai classification (table 2 and figure).

Table 1 Staging in chronic lymphocytic leukaemia

\begin{tabular}{llll}
\hline Stage & Rai staging & Binet staging & Stage \\
\hline 0 & Lymphocytosis only; no organomegaly & Enlarged nodes* in up to two areas & A \\
I & $\begin{array}{l}\text { Stage } 0 \text { with enlarged nodes } \\
\text { Liver or spleen, or both, enlarged }\end{array}$ & Three or more areas enlarged & B \\
III & $\begin{array}{l}\text { Anaemia (haemoglobin }<11 \mathrm{~g} / \mathrm{dl}) \\
\text { IV }\end{array}$ & $\begin{array}{l}\text { Anaemia (haemoglobin }<10 \mathrm{~g} / \mathrm{dl}) \\
\text { Thrombocytopenia }\left(<100 \times 10^{9} / \mathrm{l}\right)\end{array}$ & C \\
\hline
\end{tabular}

* = cervical, axillary, or inguinal nodal areas (uni- or bilateral), liver or spleen each count as one area. 
Table 2 Erythrocyte antibody inhibiting activity and tumour staging, related to staging of CLL

\begin{tabular}{|c|c|c|c|c|c|}
\hline & Stage & $\begin{array}{l}\text { No of patients } \\
(n=52)\end{array}$ & $\begin{array}{l}\text { No with antibody } \\
(n=I 1)\end{array}$ & $\%$ positive & $\begin{array}{l}\text { Erythrocyte antibody } \\
\text { inhibiting activity (\%) }\end{array}$ \\
\hline Rai & $\begin{array}{l}0 \\
\text { I } \\
\text { II } \\
\text { III } \\
\text { IV }\end{array}$ & $\begin{array}{r}16 \\
16 \\
10 \\
6 \\
4\end{array}$ & $\begin{array}{l}2 \\
4 \\
4 \\
1 \\
0\end{array}$ & $\begin{array}{l}12 \cdot 5 \\
25 \\
40 \\
16 \cdot 6 \\
0\end{array}$ & $\begin{array}{l}34,42 \\
21,31,32,55 \\
35,38,40,45 \\
37\end{array}$ \\
\hline
\end{tabular}

Lymphocyte doubling time Lymphocyte doubling times were noted for 31 untreated patients. A doubling time of less than a year was noted in five of eight $(62.5 \%)$ of those whose sera contained antibody, compared with only eight of $22(36.3 \%)$ of those without such activity, suggesting an association between a rapid doubling time and the presence of antibody.

Treatment Six of $32(19 \%)$ patients receiving treatment with chlorambucil, before or at the time of testing, showed serological evidence of EA inhibiting activity, compared with five of $20(25 \%)$ untreated patients. These differences were not significant.

Other malignant diseases Six of 52 patients $(11.5 \%)$ had other malignant diseases: carcinoma of kidney, colon, prostate, bronchus and skin (one each); a further patient had both bronchial and thyroid carcinoma. Only one of these patients had serological evidence of blocking antibody.

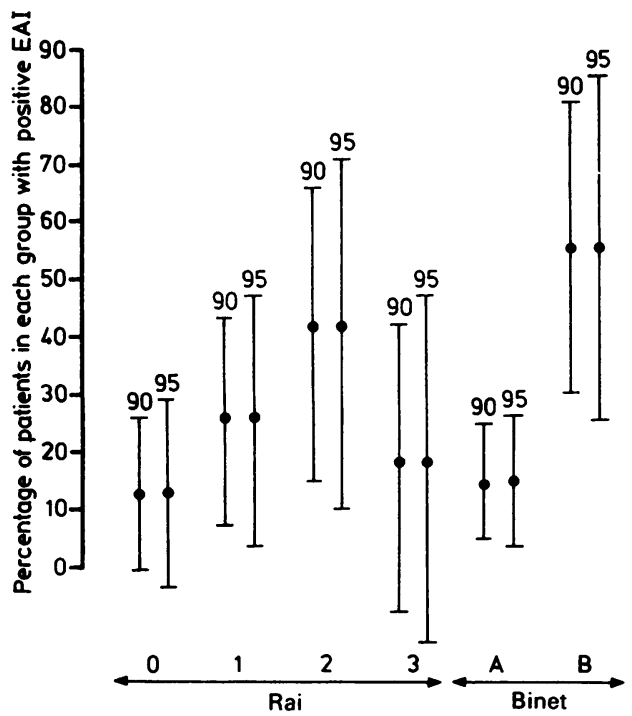

Figure Erythrocyte antibody inhibitory activity in patients with CLL according to tumour classification (with $90 \%$ and $95 \%$ confidence intervals)
Direct antiglobulin test Six of $25(11.5 \%)$ patients had a positive direct antiglobulin test, none of whom was positive for blocking antibody.

Sera from six male patients with CLL showing autologous EA inhibiting activity and who had not received blood transfusion were tested against lymphocytes from a panel of eight normal donors (table 3). Activity was noted in all sera against lymphocytes from between one and four normal donors; EA inhibiting activity in these sera was thus selective.

\section{Discussion}

This study shows that non-cytotoxic autoantibodies are present in the sera of a substantial minority of patients with CLL. These antibodies are directed towards malignant B lymphocytes and are detected by the EA inhibition assay. We have previously used this technique to identify alloantibodies associated with successful renal transplantation ${ }^{3}$ and normal pregnancy ${ }^{5}$; activity was shown to reside in IgG and $\mathrm{F}\left(\mathrm{ab}^{\prime}\right)_{2}$ fractions of serum. These antibodies may thus protect the fetus and the renal allograft from being rejected.

Studies in rodents showed that sera from animals with tumours blocked lymphocytotoxicity against tumour cells. ${ }^{1}$ The blocking factors were contained in the 7S fraction of serum, suggesting that they were antibodies. Sera from mice with viral sarcomata facilitated the growth of that sarcoma in other mice. ${ }^{13}$ The ability to transfer passively the enhancing activity proved that it was tumour specific. Furthermore, immunoglobulin has been found on the surface of human solid tumours, ${ }^{14}$ and in some instances is bound directly to tumour antigen. Thus autoantibodies in the serum of both animals and humans with tumours could bind to antigen on the malignant cells. In addition, lymphocytes from tumour bearing animals have been found to show cytotoxic activity, which can be blocked by autologous serum. ${ }^{2}$ These studies in rodents suggest that certain antibodies to tumour antigens may have an immunosuppressive role. 
Table 3 Erythrocyte antibody inhibitory activity in sera from untransfused male patients with CLL directed against $B$ lymphocytes from a normal panel

\begin{tabular}{|c|c|c|c|c|c|c|c|}
\hline \multirow{2}{*}{\multicolumn{2}{|c|}{$B$ lymphocyte panel members and tissue types }} & \multicolumn{6}{|c|}{ CLL sera ( $\%$ inhibition) } \\
\hline & & Case I & Case 2 & Case 3 & Case 4 & Case 5 & Case 6 \\
\hline $\begin{array}{l}\text { A } 1,3 \\
\text { A2,3 } \\
\text { A } 9,10 \\
\text { A } 1,2 \\
\text { A2,11 } \\
\text { A2,3 } \\
\text { A2,11 } \\
\text { A2,10 }\end{array}$ & $\begin{array}{cl}\text { B8,17 } & \text { DR3,7 } \\
\text { B7,44 } & \text { DR2,5 } \\
\text { B55,8 DR5 } & \text { DR } \\
\text { B8 DR3,7 } \\
\text { B15,35 } & \text { DR5 } \\
\text { B5,18 } & \text { DR2,3 } \\
\text { B7,21 } & \text { DR6,7 } \\
\text { B7,12 } & \text { DR2 }\end{array}$ & $\begin{array}{l}<20 \\
<20 \\
<20 \\
<20 \\
<20 \\
<20 \\
\text { Not tested } \\
>20\end{array}$ & $\begin{array}{l}<20 \\
<20 \\
<20 \\
>20 \\
<20 \\
<20 \\
<20 \\
<20\end{array}$ & $\begin{array}{l}>20 \\
<20 \\
>20 \\
>20 \\
<20 \\
<20 \\
>20 \\
<20\end{array}$ & $\begin{array}{l}<20 \\
>20 \\
<20 \\
<20 \\
<20 \\
<20 \\
>20 \\
<20\end{array}$ & $\begin{array}{l}<20 \\
<20 \\
<20 \\
>20 \\
>20 \\
<20 \\
<20 \\
<20\end{array}$ & $\begin{array}{l}>20 \\
<20 \\
<20 \\
<20 \\
<20 \\
<20 \\
>20 \\
<20\end{array}$ \\
\hline
\end{tabular}

The autoreactive $\mathrm{Fc}$ receptor blocking antibodies identified in this study differ from those we have found previously. ${ }^{15}$ Firstly, as autoantibodies occurred in several patients without a history of either previous blood transfusion or pregnancy, it is unlikely that they developed as a result of previous alloantigenic exposure. Secondly, we have been unable to detect antibody activity against autologous B lymphocytes in sera from patients receiving dialysis, ${ }^{15}$ or in serum from normal donors. ${ }^{16}$ These observations suggest that the $F c$ receptor blocking antibodies in CLL occur in response to antigens on the tumour cells themselves, although we have no direct evidence that they have a protective role. They are, however, present in sera from patients irrespective of whether they have received treatment. It is thus unlikely that their development reflects a change in immune response caused by chemotherapy.

Sera from five male patients with CLL who had not received blood transfusions but with antibody activity against their malignant B lymphocytes, also showed reactivity against lymphocytes from selected members of a normal panel. This suggests that the autoantibodies cross react with antigens carried on certain normal B lymphocytes. This activity was not in accordance with the HLA, A B, or DR type carried by the panel cell, indicating that these were not the target antigens.

Alloantibody activity in sera obtained during pregnancy and after blood tranfusion similarly failed to correlate with the tissue type of the panel target cells. Selected sera, however, were tested against lymphocytes from family members and activity was shown to be HLA linked; other HLA coded antigens may thus be present on lymphocyte surfaces. There is some evidence for a common mechanism of synthesis shared by tumour and major histocompatibility complex antigens, ${ }^{17}$ and one study in mice showed virtual identity between certain oncogenes and genes coding for histocompatibility antigens near the $\mathrm{Qa} / \mathrm{Tla}$ locus. ${ }^{18}$ An antibody against a tumour antigen may thus cross react with major histocompatibility com- plex coded antigens on certain normal cell surfaces.

EA inhibitiory activity was detected more commonly as tumour load increased, as measured by clinical staging. Similarly, there was a trend towards increasingly common antibody detection in sera from patients with rapid lymphocyte doubling times. When marrow failure supervened, antibody activity was found less commonly, and this may have been related to a general failure to produce antibodies.

In conclusion, non-cytotoxic EA inhibiting antibodies have been found in sera from some patients with CLL, directed against autologous malignant B lymphocytes; as far as we know, this has not been described previously. These antibodies were more often present when the tumour load was higher. Noncytotoxic autoantibodies may be induced by antigens on the malignant B lymphocytes and may bind to these antigens, so becoming possible candidates for antibodies that permit tolerance of the tumour by the host.

We thank Mr K Stewart and Miss June Cameron for technical help and Mrs Caroline Baird for typing the manuscript.

Miss Minford received a grant from the Scottish Home and Health Department.

\section{References}

1 Hellstrom I, Hellstrom KE. Studies on cellular immunity and its serum mediated inhibition in Malony virus induced mouse sarcomas. Int J Cancer 1969;4:587-600.

2 Lachman P. Tumour immunology: a review. J Roy Soc Med 1984;77:1023-9.

3 MacLeod AM, Mason RJ, Stewart KN, et al. Association of Fc receptor blocking antibodies and human renal transplant survival. Transplantation 1982;34:273-9.

4 MacLeod AM, Power DA, Mason RJ, et al. Possible mechanism of action of transfusion effect in renal transplantation. Lancet 1982;ii:468-70.

5 Power DA, Catto GRD, Mason RJ, et al. The fetus as an allograft: Evidence for protective antibodies to HLA-linked paternal antigens. Lancet 1983;ii:701-4.

6 Rai KR, Sawitsky A, Cronkite EP, Chanana AD, Levy RN, Pasternack BS. Clinical staging of chronic lymphocytic leukaemia. Blood 1975;46:219-34. 
7 Binet J-L, Catovsky D, Chandra P, et al. Chronic lymphocytic leukaemia: proposals for revised prognostic staging system. Br J Haematol 1981:48:365-7.

8 Montserrat E, Sanchez-Bisono J, Vinolas N, Rozman C. Lymphocyte doubling time in chronic lymphocytic leukaemia: analysis of its prognostic significance. $\mathrm{Br} J$ Haematol 1986:62:567-75

9 Stewart KN, Separation of T and B lymphocytes by nylon fibre columns. Med Lah Sci 1981:38:123-5.

10 Soulillou JP, Carpenter CB, d A pice AJF. Strom TB. The role of non-classical $\mathrm{Fc}$ receptor associated $\mathrm{Ag}-\mathrm{B}$ antigens (Ia) in rat allograft enhancement. J Exp Med 1976;143:405-21.

11 Power DA, Cunningham C. Catto GRD. The role of RT1 antigen differences in semi allogeneic rat pregnancy. Clin Sci 1987;72:37-45

12 Hill A. Principles of medical statistics. London: The Lancet 1971:122-32

13 Pierce GE. Enhanced growth of primary Maloney virus-induced sarcomas in mice. Int $J$ Cancer 1971;8:22-31.

14 Seth P. Balchandran N. Elution of herpes simplex virus specific cytotoxic antibodies from squamous cell carcinoma of the uterine cervix. Nature 1980;286:613-5.
15 MacLeod AM, Mason RJ, Power DA, et al. Evidence that protective Fc-receptor-blocking antibodies in renal transplantation are alloantibodies not autoantibodies. Transplantation 1985:39:520-3.

16 Stewart GM. Mason RJ. Thomson MAR. MacLeod AM. Catto GRD. Non-cytotoxic antibodies to paternal antigens in maternal sera and placental eluates. Transplantation 1984:38:112-5.

17 Curry RA. Cluaranta V. Wilson BS. et al. Expression of HLA antigens on cultured human melanoma cells: Lack of association with melanoma associated antigens. In: Ferrone $S$. Gormi S, Herberman RB. Reisfield RA. eds. Current trends in tumor immunology. New York: Garland STPM Press. 1979:347-66.

18 Brickell PM. Latchman DA. Murphy D. Willison K. Rigby WJ Activation of a $\mathrm{Qa} / \mathrm{Tla}$ class $\mathrm{I}$ major histocompatibility antigen gene is a general feature of oncogenesis in the mouse. Nature 1983:306:756-60.

Requests for reprints to: Dr AM MacLeod. Lecturer in Medicine. Polwarsh Buildings. Foresterhill. Aberdeen AB9 2ZD. Scotland 